ISSN 1991- 8690

website :http:// jsci.utq.edu.iq

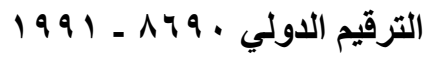

Email: utjsci@utq.edu.iq

\title{
Streptopelia senegalensis and White-breasted Kingfisher, Halcyon smyrnensis
}

\author{
Marwa Jamal Al- Kinany
}

\author{
Adnan Waheed Al- Bideri
}

Jafar Abbas Al- Maamori

\begin{abstract}
$\underline{\text { Abstract }}$
The aim of the current work was to study the histological structures of glandular stomach, the proventriculus and compare it in two types of Iraqi wild birds according to differences in diets. The birds are, Laughing dove, Streptopelia senegalensis which comprised the grainivorous bird and white breasted Kingfisher Halcyon smyrnensis which comprised the carnivorous bird. The results exhibited that the wall of the stomach (proventriculus) of two birds consists of the four layers of typical tubular organ: tunica mucosa, submucosa, muscularis and serosa. The tunica mucosa of two birds consisted of three layers, epithelium, lamina properia and muscularis , the free surface of two birds is covered with circular plicae modified from of the mucosa, The surface lining cells of this folds in both of birds is simple columnar with clear cytoplasm. The lamina propria is constituted by connective tissue with blood vessels and lymphocitary infiltration. As well as simple tubular glands. Notice that these glands are lining by simple columnar in white breasted kingfisher while simple cuboidal to columnar in laughing dove. Muscularis mucosa was a smooth muscle fibers, appears scattered along the lamina propria in laughing dove surrounds the apical part of deep proventricular glands, and extend inside the proventricular folds and entirely around the deep proventricular glands in white breasted kingfisher. Submucosa layer occupy most of the real area of the proventriculus wall containing numerous deep proventricular glands that occupy great part of submucosa. This layer is thicker in kingfisher as compared with laughing dove. Each secretory region is a well-defined unit and enclosed by a connective tissue capsule contains bloods vessels and nerves. These gland are compound tubular branched glands, each gland consists of numerous of secretory tubules. These tubule leads to ducts and open into central collecting duct that opens in the proventricular lumen. The secretory tubules of deep glands lining by simple cuboidal cells represent chief cells that secreting hydrochloric acid and pepsinogen. the tunica muscular (tunica muscularis) of two birds consist of two layers, inner circular muscle layer and outer longitudinal muscle layer, inner layer is thicker in kingfisher as compared to laughing dove. Between these two muscular layers, blood vessels and nervous plexus (Auerbach) are found. The tunica serosa consisted of connective tissue contains nerves, blood vessels and ganglionic cells of serous plexus.
\end{abstract}

\section{دراسة نسجية مقارنة للمعدة ( الجزء الغدي) بين الحمام الضاحك Streptopelia senegalensis و الرفراف ابيض Halcyon smyrnensis الصدر}

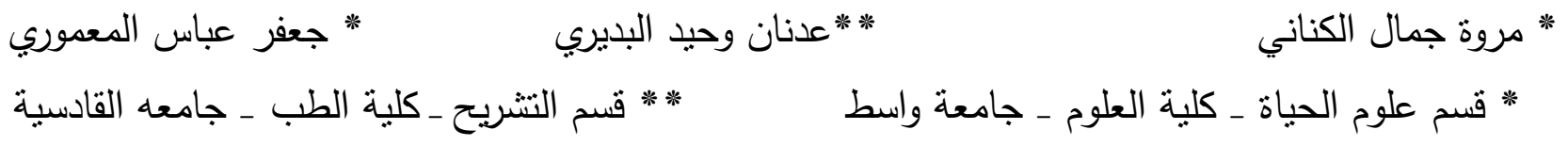

الخلاصة

يستهدف البحث اجراء دراسة نسجية مقارنة للمعدة (الجزء الغدي) في نوعين من الطيور البرية العراقية تبع الأختلاف في نوع الغذاء ، احدهما طائر فاختة النخيل او مايسمى باليمام الضاحلك Streptopelia senegalensis حيث يعد من الطيور آكلات الحبوب والآخر طائر الرفراف ابيض الصدر Halcyon smyrnensis وهو من الطيور آكلات اللحوم. اظهرت النتائج ان جدار المعدة الغدية في كلا الطائرين يتكون من الطبقات الاربع التي يتكون ماتئ منها العضو الانبوبي النموذجي وتلك الطبقات هي : الطبقة المخاطية، تحت المخاطية، العضلية والمصلية ، وجد ان الطبقة المخاطية لكلا الطائرين تتكون 
من الظهارة ، الصفيحة الأصيلة والعضلية المخاطية ،وان السطح الحر للخلايا الطلائية في كلا الطائرين مغطى بطيات دائرية Plicae circulars متحورة عن الطبقة المخاطية، حيث ثُبطن هذه الطيات في كلا الطائرين بواسطه خلايا طلائية عمودية ذات سايتوبلازم رائق او شفاف. اما الصفيحة الأصيلة فنكونت من نسيج ضام يحتوي على أوعية دموية ومواد لمفية منرشحة، فضلا عن وجود غدد انبوبية بسيطة. لوحظ ان هذه الغدد مبطنة بخلايا عمودية في طائر الرفراف اما في طائر الفاختة وجد انها تبطن بواسطة خلايا مكعبة الى عمودية. اما بالنسبة للطبقة العضلية المخاطية اظهرت النتائج انها عبارة عن الياف عضلية ملساء تظهر بصورة مُتقطعة على طول الصفيحة الاصيلة تحيط الجزء القمي للغدد تحت المخاطية العميقة لطائر فاخته النخيل ، بينما تمتد داخل طيات المعدة الغدية وتحيط بالغدد تحث المخاطية العميقة تقريبا بصورة كاملة في طائر الرفراف ـ شغلت الطبقة تحت المخاطية اغلب مساحه جدار المعدة الغدية واحتوت على عدد كبير من الغدد العميقة التي تحنل جزء كبير من هذه الطبقة. اظهر الوصف النسجي ان هذه الطبقة تكون سميكة في طائر الرفراف مقارنة بطائر فاختة النخيل. وان كل غدة عميقه تمثل منطقة محددة محاطة بمحفظة من نسيج ضام يحتوي على اوعية دموية واعصاب. نكون هذه الغدد من النوع المركب الانبوبي المنقرع وتكونت كل غدة في نوعي الطيور من نُبيات افرازية عديده تؤدي الى قنوات اخرى لنُفتح في قناه مركزية جامعه تُقتح في تجويف المعدة الغدية. تبطن هذه النبيبات بخلايا مكعبة بسيطة تمنل الخلايا الرئيسة التي تفرز حامض الهيدروكلوريك وانزبم البيسين ـ اما الطبقة العضلية فلوحظ انها تتكون من طبقتين من الالياف العضلية تترتب الداخلية منها بصورة دائرية اما الخارجية فتترتب بصورة طولية. واتصفت الطبقه الداخلية في طائر الرفراف بكونها اسمك مقارنة بطائر فاخته النخيل ، ولوحظ وجود أوعية دموية وضفيرة اوربخ العصبية بين هاتين الطبقتين. اما الطبقة الخارجية المصلية فظهرت مكونه من نسيج ضام يحتوي أوعية دمويه واعصاب وخلايا عصبية للضفيرة المصلية.

\section{Introduction}

Animal's diet may change dramatically due to changing food availability, or differing requirements for energetically demanding reproduction or moult (Moore $\&$ Battley, 2006). Digestive system and gut morphology show considerable variation among animals, depending on phylogenetics, diet quality, the size of the animal and differing environmental pressures (Davis,2007). The most active part of the digestive system of birds is a stomach which is formed of two distant parts; proventriculus or true stomach and the muscular portion vetriculus or gizzard (Ahmed et al., 2011).Histologically the wall of the stomach (proventriculus and gizzard) is constituted by the following layers: tunica mucosa, submucosa, muscular and tunica serosa (Catroxo et al., 1997). The proventriculus serves as the glandular stomach of birds (Wideman et al., 1996) which presents an eliptical shape, relatively thick-walled structure located at the distal end of the oesophagus. The tunica mucosa of proventriculus presents folds (plicae) in its luminae surface. The lamina propria is constituted by connective tissue with blood vessels and lymphocitary infiltration. In its interior, simple tubular glands are found. The submucosa is constituted by connective tissue and deep proventricular glands are located in it (Catroxo et al, 1997). Tunica muscularis is slightly modified and the inner longitudinal, circular and outer longitudinal layers are found, the tunica serosa is composed by connective tissue and cuboidal cells layer (Rossi et al., 2005). The proventriculus varies in size between species, being relatively small in graminivores, but often quite large and distensible in carnivores that ingest large food items and in ostriches use it for water storage (Duke, 1997). So the aim of this work was to investigate and comparative the histological differences of stomach (proventriculus) in two species of Iraqi wild birds, Laughing dove, Streptopelia senegalensis, belongs to family Columbidae, (Schleucher, 2001) with distribution extends across Africa (Hockey et al., 2005), and found locally in Palestine, Syria, Lebanon, Egypt and Iraq (Lahony et al., 2008). This species is a generalist granivorous and consider an important model for physiological and behavior studies (Johnson et al., 2001).The other bird, White-breasted Kingfisher Halcyon smyrnensis (Aves: Coraciiformes) which is a common species of a variety of habitats, mostly open country in the plains with trees, electric wires. It is the most common carnivorous (Ali \& Asokan, 2010) which feed upon fish, grasshoppers and mice, also upon large insects, crustaceans forms a major part of their diet (Soud et al., 2010). This species is found in Turkey, Palestine, Egypt, Iraq, Afghanistan.

\section{Materials and Methods}

\section{Birds and feeding}

Twenty healthy birds laughing dove (Streptopelia senegalensis) and white breasted kingfisher (Halcyon smyrnensis) (males and females) were captured in the city of Kut, Iraq (ten birds from each species) and kept in individual cages, for a short period. They were fed 
with grains, insects and fishes similar to those existent in the area of capture. The birds were prepared for histological

study.

\section{Processing for light microscopy}

Twenty healthy birds were collected and body weight was recorded. The birds were anesthetized with chloroform inhalation. Anatomical observation (weight, position and dimensions) of stomach for each species was recorded. For the histological study, the digestive tube was exposed and fragments of stomach (proventriculus) were immediately fixed in $10 \%$ buffer neutral formalin for 72 hours. The specimens were dehydrated in ascending grades of ethyl alcohol and clearing in xylol, then embedded in paraffin wax, sectioned at (5-6 $\mu \mathrm{m})$ thickness and mounted, then stained by haematoxylin-eosin stain for general examination (Bancroft \& Stevens, 1982). Later, histologic sections were examined in light microscope, analyzed and described histologically.

\section{$\underline{\text { Results }}$}

The stomach of birds consists of a glandular proventriculus and muscular ventriculus. The glandular portion is a fusiform organ lying dorsal to the liver between the esophagus and the gizzard. The histological analysis, under light microscopy, revealed that the wall of the stomach (proventriculus) of two birds laughing dove (Streptopelia senegalensis) and white breasted kingfisher (Halcyon smyrnensis) has all the four layers of typical tubular organ: tunica mucosa, submucosa, tunica muscularis and tunica serosa (fig. 1, 2 ). The tunica mucosa of two birds consisted of three layers, epithelium, lamina properia, and Muscularis mucosa as in other birds; the free surface of two birds is covered with circular plica of the mucosa (fig. 2). The surface lining cells of this folds in both of birds is simple columnar with clear cytoplasm (fig. 3). The lamina propria is constituted by connective tissue with blood vessels and lymphocitary infiltration. And extend inside the folds. Simple tubular glands are found in this propria (fig. 4, 5). In kingfisher these glands are lining by simple columnar epithelium and opened in the bases of mucosa folds ( fig. 4), furthermore they were numerous, larger and extend deeper in the lamina propria of kingfisher as compared to laughing dove in which they were lining with simple cuboidal to columnar epithelium and distributed in the apical part of lamina propria( fig.5).Muscularis mucosa is a smooth muscle fibers, Appears scattered along the lamina propria in laughing dove and surrounds the apical part of deep proventricular glands( fig. 1), While in kingfisher appears as smooth muscle layer extend inside the proventricular folds and entirely around the deep proventricular glands that lies beneath the muscularis mucosa (fig. 2). The second tunic, submucosa was constituted by connective tissue, containing blood vessels, This tunic occupy most of the real area of the proventriculus wall containing numerous deep proventricular glands that occupy great part of submucosa( fig1,2). Each secretory region is a well-defined unit and enclosed by a connective tissue capsule contains bloods vessels and nerves, which separate glands from each other to outlines and defines the limit of gland. Deep proventriculus gland are compound tubular branched glands with secretory tubules( fig. 6,7), This glands appears as conical shape in laughing dove ( fig. 8), and long cylindrical shape in white breasted kingfisher( fig.9). Each gland consists of numerous of secretory tubules. These tubule leads to ducts and open into central collecting duct that opens in the proventricular lumen (fig. 6, 7). The secretory tubules of deep glands lining by simple cuboidal cells present chief cells that secreting hydrochloric acid and pepsinogen. The collecting duct of deep glands open inside the gastric lumen through main duct lining by simple columnar cells with clear cytoplasm in white breasted kingfisher ( fig.7) while open directly into stomach in laughing dove(fig.6). The tunica muscularis of two birds consist of two layers, inner circular and outer longitudinal. The result shows that inner layer is thicker than outer in kingfisher (fig. 11). While in laughing dove, the outer layer is thicker than the inner (fig. 10). Between these two muscular layers, blood vessels and nervous plexus (Auerbach) are found. The tunica serosa is consist of connective tissue contains nerves, blood vessels and ganglionic cells of serous plexus (fig. 9). 


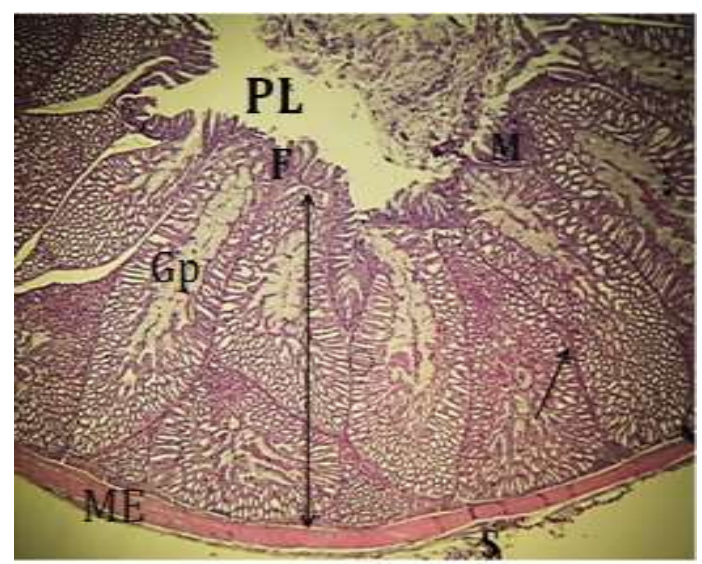

Fig 1: Photomicrography of the cross section of laughing dove proventriculus wall: Proventriculus lumen (PL), folds of mucosa (F), mucosa (M),deep proventricular glands (GP), capsule of gland (arrow), submucosa $(\mathrm{Sm})$, muscularis externa (ME), serosa(S),Hematoxylin and Eosin stain (40x)

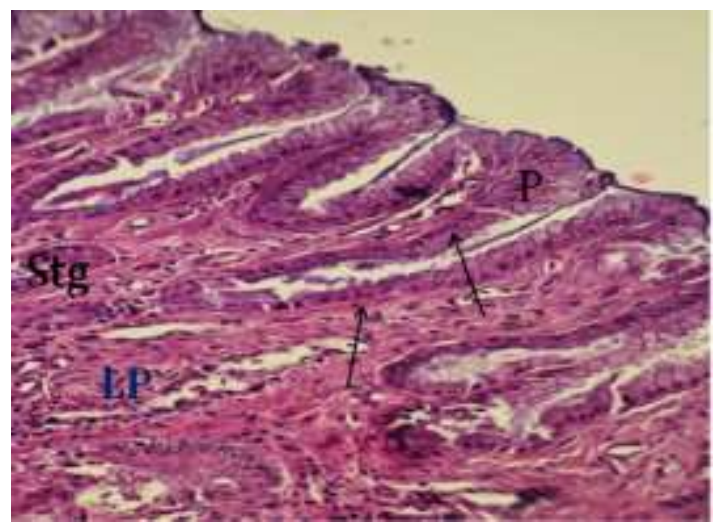

Fig 3: Photomicrography of the longitudinal section of mucosa in white breasted kingfisher show the mucosal folds, Plica, (P), surface lining cells (arrow), simple tubular glands (Stg), lamina propria (Lp), H\&E stain, 400x

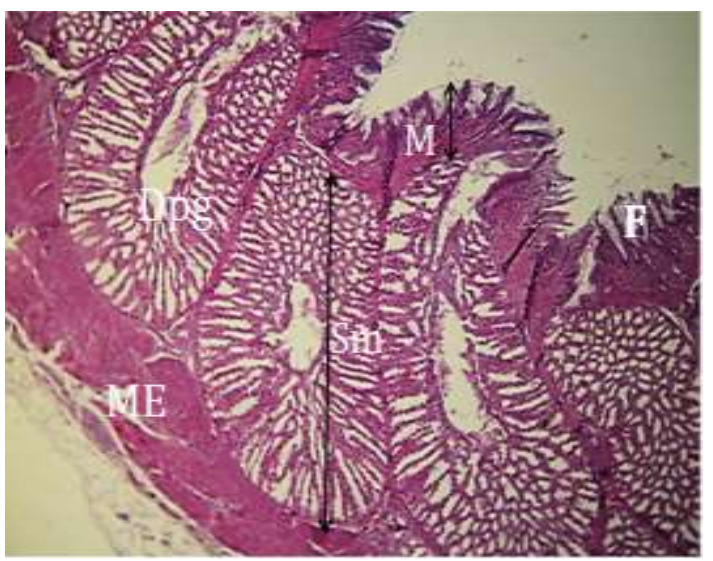

Fig2: Longitudinal section of white breasted kingfisher proventriculus wall: mucosa layer (M), submucosa layer (Sm), deep proventriculus glands of submucosa (Dpg), muscularis externa (ME), H\&E stain, (100X)

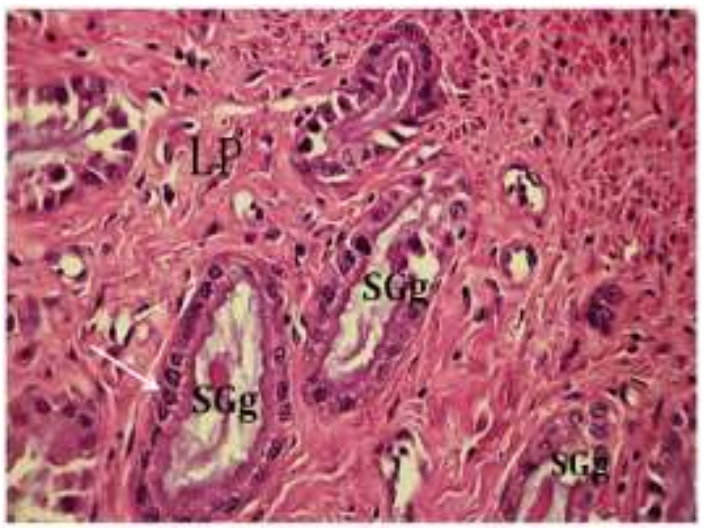

Fig 4: Photomicrography show the simple tubular glands of mucosa proventriculus in white breasted kingfisher, lamina propria (LP), superficial gastric glands ( $\mathrm{SGg}$ ), nucleus (arrow), H\&E stain, $400 \mathrm{x}$ 


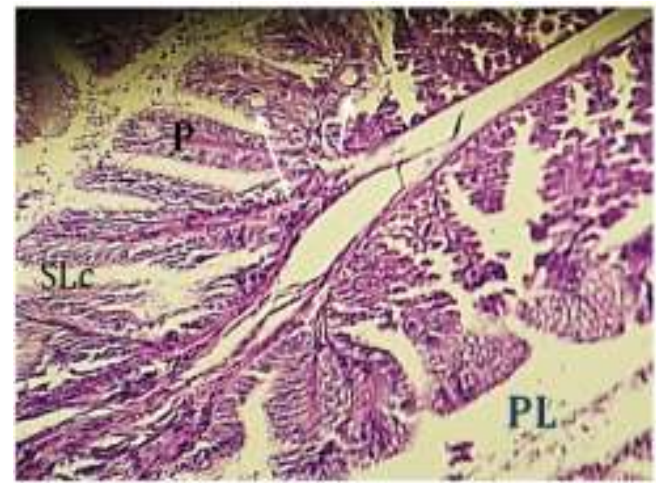

Fig 5: Photomicrography of the cross section of mucosa in laughing dove show the mucosal plica $(\mathrm{P})$, surface lining cells

(SLc), simple tubular glands (arrow), proventriculus lumen, $\mathrm{H} \& \mathrm{E}$ stain, $100 \mathrm{x}$

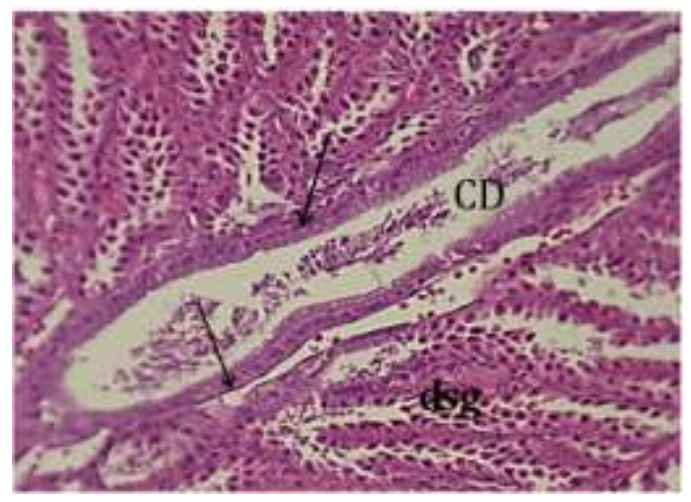

Fig 7: Photomicrography of the longitudinal section of submucosal gland in white breasted kingfisher show the central duct (CD), of deep gland (dsg), lining columnar cells of central duct(arrow), H\&E stain, 400X.

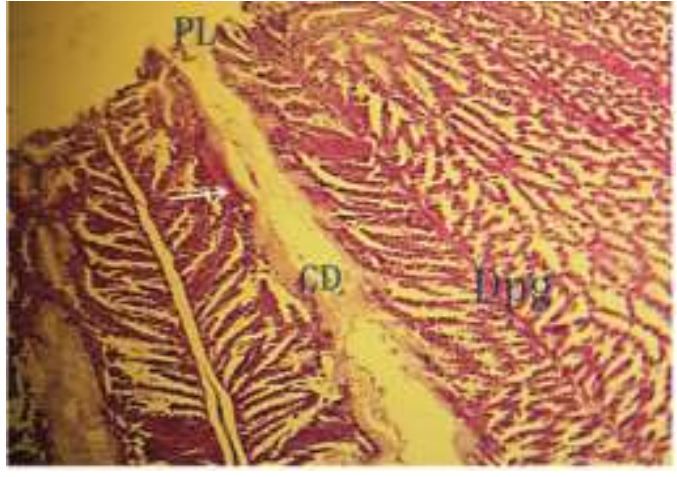

Fig 6: Photomicrography of the central duct of laughing dove: proventriculus lumen (PL), lining columnar cells of central duct (arrow), central duct (CD), deep proventriculus glands (Dpg), H\&E stain, 100X

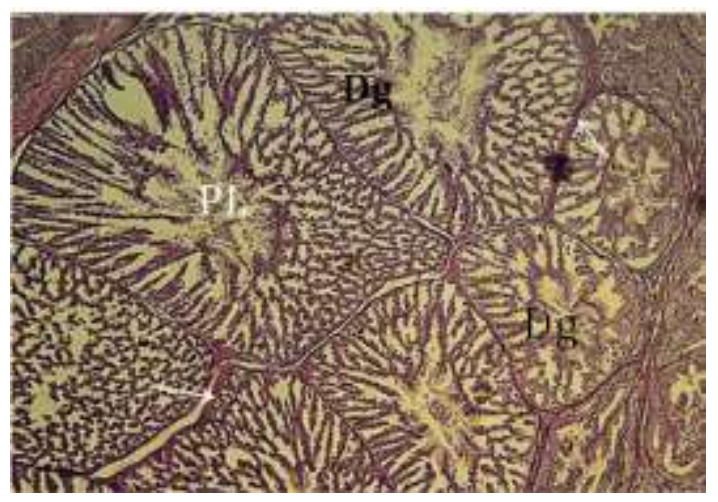

Fig8: Transverse section show the submucosal glands of laughing dove: deep proventriculus glands $(\mathrm{Dg})$, connective tissue capsule (arrow), proventriculus lumen (PL), H\&E stain40 X. 


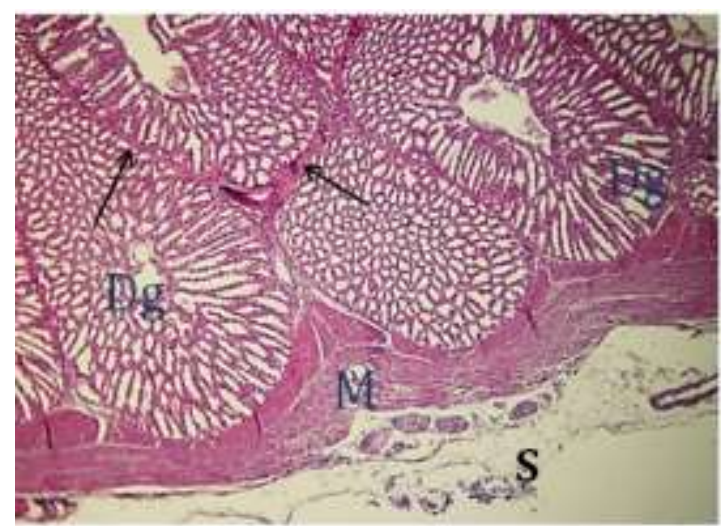

Fig9:Longitudinal section show the submucosal glands of white breasted kingfisher: deep proventriculus glands (Dg), connective tissue capsule (arrow), tunica muscularis (M), serosa (S),H\&E stain, 100X

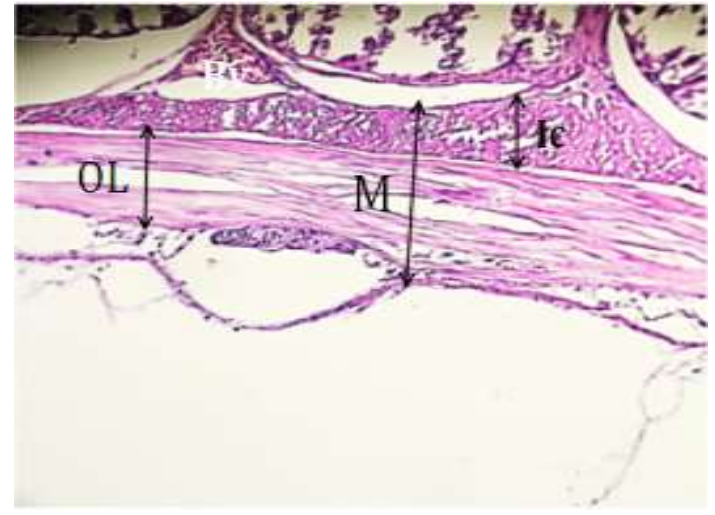

Fig 10: Photomicrography of longitudinal section of the tunica muscularis in laughing dove: total tunica muscularis (M), inner circular layer (Ic), outer longitudinal layer (OL), blood vessel (Bv), H\&E stain, 400 X

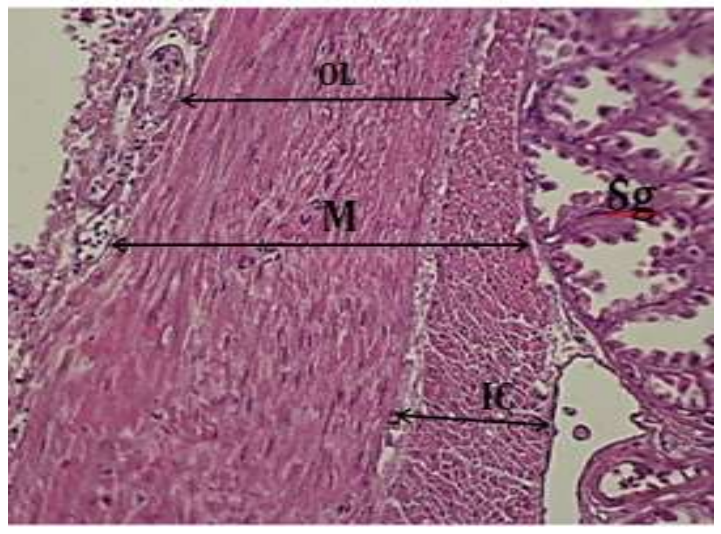

Fig 11: Longitudinal section of tunica muscularis in kingfisher: deep submucosal glands (Sg), total tunica muscularis (M), inner circular layer (Ic), outer longitudinal layer

(OL), H\&E , 400X

\section{Discussion}

The analysis of histological sections, under light microscopy, shows that the wall of the proventriculus of two birds is consisted of four layers: tunica mucosa, submucosa, tunica muscularis and tunica serosa, The same finding was observed by (Catroxo et al ., 1997) on red-capped cardinal , (Rossi et al., 2005 ; Illanes et al., 2006) on Partrigde and Struthio camelus respectively , (Selven et al., 2008) on Guinea fowl, (Tadjalli et al., 2011) on Ostrich, but disagree with (Marshall\& Folley, 1965) who considered the existence of only three tunics. The present work showed that the tunica mucosa of two birds consisted of three layers, epithelium, lamina properia, and muscularis mucosa as in other birds; the mucosa of the proventriculus was thrown into folds of varying height termed plicae circulars. This finding was in agreement with the results of Rocha and Lima, (1998); Catroxo et al., (1997) and (Ahmed et al., (2011) who mentioned the presence of 
these folds. The surface lining cells of proventriculus folds was simple cuboidal to columnar with clear cytoplasm. As revealed by Rocha and Lima, 1998; Selven et al., 2008) this cell secrete mucus. This mucous secretion acts as a protective lining for the surface of epithelium from the action of acids (Bacha and Bacha, 2000). The lamina propria is constituted by connective tissue with blood vessels and lymphocitary infiltration. In its interior, simple tubular glands are found. These findings agree with many previous studies such as Rocha and Lima, (1998); Catroxo et al., (1997); Rossi et al., (2005) that confirm the presence of these glands. In white breasted kingfisher these glands are lining by simple columnar epithelium similar histological observations mentioned by Catroxo et al., (1997) on their study on red-capped cardinal and Alsheshani,( 2006) in his study on carnivorous bird, Accipiter nisus, while lining by simple short columnar to cuboidal in laughing dove and opens in the bases of mucosa folds, This finding is in agreement with Alsheshani, (2006) in his work on Columba Livia, Some authors Rocha and Lima, (1998); Farner, (1960) mention that the lining cells of these glands are simple cuboidal. The histological analysis showed that these glands that are numerous, larger and extend deeper in the lamina propria as compared to laughing dove, where distributed in the apical part of lamina propria. Beneath lamina propria, as revealed in present study isolated smooth muscle of muscularis mucosa was found as scattered fibers along the lamina propria in laughing dove and surrounds the apical part of deep proventricular glands, while in white breasted kingfisher appeared more clearly as smooth muscle layer extend inside the proventricular folds and entirely around the deep proventricular glands that lies beneath the muscularis mucosa. This finding is in agreement with El-Banhawy et al., (1993); Alsheshani, (2006), who confirmed the presence of muscularis mucosa. The tunica muscularis is composed of two muscle fibers layers as mentioned by Rocha \& Lima, (1998), Rossi et al., (2005); Attia, (2008); Ahmed et al., (2011), Albideri et al., (2011) on the other hands Banks, (1992), Catroxo et al., (1997); El-Banhawy et al.,( 1993) who mentioned the presence of three layers of muscle fibers. The inner layer was arranged circularly, where the outer layer have longitudinal disposition in both of birds as described by Rocha \& Lima,( 1998); Ahmed et al.,( 2011), the histological analysis showed that the inner layer in kingfisher is thicker than the outer while it was reverse observe in the laughing dove . Between these two muscular layers, blood vessels and nervous plexus (Auerbach) are found. The tunica serosa in both of birds was consisted of connective tissue contains nerves, blood vessels and ganglionic cells of serous plexus as found in previous studies Rocha and Lima,( 1998); Catroxo et al.,( 1997). It is concluded that the kind of diet reflects some histological differences in the glandular stomach of the two studied birds appears in the thickness of the layers that composed the glandular stomach.

\section{References}

Ahmed, Y. A. E.; Kamel, G. and Ahmed, A. A. E. (2011). Histomorphological studies on the stomach of the Japanes Quail. Asain J. Poult. Sci., 5(2): 56-67.

AL Sheshani, A. S. Y., (2006).Anatomical and Histological Comparative study of alimentary tract in two types of bird's grainivorous bird, (Columba livia Gmelin, 1789) and carnivorous bird, (Accipiter nisus Linnaeus, 1758). M.Sc.Thesis. University of Tikrit.

Albideri, A. W.; Haba, M. K. and Kadum, M. J., (2011). Histological study of gastrointestinal tract in Squacco heron Ardeola ralloides and Rock dove Columba livia. Al-Kufa Uni., Journal of Biology, 2(3).

Ali, A. M. S. and Asokan, S. (2010). Observations on nesting ecology of White-breasted Kingfisher Halcyon smyrnensis (Aves: Coraciiformes) in Cauvery Delta, Southern India. J. of Ecology and the Natural Environment, 2(7): 134-139.

Attia, H. F., (2008). Some histological studies on the proventriculus of the quail during pre and post hatching periods. Minufiva Vet.J. 5(2): 442-453.

Bancroft, J. D. and Stevens, A., (1982). . In Theory and practice of histological techniques. 2nd (Ed). Churchill Livingstone. New York.

Banks, W.J. (1992). Histologia veterinaria aplicada. 2nd.ed, Sao Paulo: Manole, pp.629. From (AL Sheshani, 2006).

Bacha, W. J. and Bacha, L. M. (2000). Color atlas of veterinary histology. 2nd. Ed., Lippincott Williams \& Wilkins, Ames, Iowa, USA.

Catroxo, M. H. B.; Lima, M.A.I. and Cappellaro, C.E.M.P.D.M., (1997). Histological aspects of the stomach (proventriculus and gizzard) of the Red-Capped Cardinal (Paroaria gularis gularis). Rev. chill. anat., v.15 n.1. 
Davis, S. (2007). Endozoochory in the subtropical thicket: Comparing effects of species with different digestive systems on seed fate. M.Sc. Thesis. Faculty of Science. Nelson Mandela Metropolitan University

Duke, G. E. (1997). Gastrointestinal physiology and nutrition in wild birds. Proceedings of the Nutrition Society, 56: 1049- 1056.

El-Banhawy, M. A.; Mohallal, M. E.; Rahmy, T. R. and Moawad, T. I. (1993). Histological adaptation in the Digestive organs of birds with various dietary peculiarities. J. Egypt. Ger. Soc. Zool. 12c: 153-170. From (AL Sheshani, 2006).

Farner, D. S., (1960). Digestion and digestive system. In: Biology and comparative physiology of Birds, Marshall, A. J. (Ed). Vol.1, Academic Press, New York. Cited by From Ahmed, Y. A. E.; Kamel, G. and Ahmed, A. A. E. (2011). Histomorphological studies on the stomach of the Japanes Quail. Asain J. Poult. Sci., 5(2): 56-67.

Hockey, P.A.R., Dean, W.R.J and Ryan, P.G. (Eds) (2005). Birds of Southern Africa VII10th edition. The Trustees of the John Voelcker Bird Book Fund, Cape Town, 281-284.

Illanes, J.; Fertilio, B.; Chamblas, M.; Leyton, V. and Verdugo, F. (2006). Descripción Histológica de los Diferentes Segmentos Del Aparato Digestivo de Avestruz (Struthio camelus var. domesticus). Int. J. Morphol., 24(2):205-214.

Johnson, k. P. ; Kort, S. D. ; Dunwoody, K. ; Mateman, A. C. ; Cate, C. T. ; Lessells, C. M. and Clayton, D. H. (2001). A Molecular phylogeny of the Dove genera Streptopelia and Columba. The Auk, 118(4):874-887.

Lahony, S. R.; Mohammad, M. K. and Ali, H. A. (2008). A New record of gosh hawk (Baz) Accipiter gentilis (Aves-Falconiformrs) with short notes on distribution of laughing dove Slreptopelia senegalensis (Aves Columbiformes) in. Bull. Iraq nat. Hist. Mus., 10(3): 45-47.

Marshall, A. J. and Folley, S. J. (1965). The origin of nest-cement in edible-nest swiftlets (Collocalia spp). Proc. Zool. Soc. Lond., 12: 383-9. Cited by From Rocha, S. D. O.; Lima, M. A. I., (1998). Histological aspects of the stomach of burrowing Owl. Rev. Chil. Anat. 16(2): 191-197.
Moore, S. J. and Battley, P. F. (2006). Differences in the digestive organ morphology of captive and wild Brown Teal Anas chlorotis and implications for releases. Bird Conservation International, 16: 253-264.

Rocha, S. D. O. and Lima, M. A. I., (1998). Histological aspects of the stomach of burrowing Owl. Rev. Chil. Anat. 16(2): 191-197.

. Rossi, J. R.; baraldi-Artoni, S. M.; Oliveira, D.; Cruz, C. D.; Franzo, V. S. and Sagula, A. (2005). Morphology of glandular stomach (Ventriculus glandularis) and muscular stomach (Ventriculus muscularis) of the partrigde Rhynchotus rufescens. Ciencia Rural, Santa Maria, vol. 35, n. 6 Pp: 1319-1324.

Schleucher, E. (2001). Heterothermia in pigeons and doves reduces energetic costs. Journal of Thermal Biology, 26, 287-293.

Selven, P. S.; Ushakumary, S. and Ramesh, G., (2008). Studies on the Histochemistry of the proventriculus and gizzard of post hatch Guinea fowl. Int. J. Poult. Sci., 7(11): 1112-1116.

Soud, R.; Mazumdar, K. and Gupta, A., (2010). Predation by White-throated Kingfisher Halcyon smyrnensis on Common wolf Snake Lycodon aulicus (Linnaeus), NeBIO, 1(1): 53-54.

Tadjalli M.; Parto, P. and shahraki, A. F., (2011). Histological study of proventriculus of male adult Ostrich. Global Veterinaria, 7(2): 108-112.

Wideman, R.R., Jr., Y.K. Kirby, G.R. Bayyari., (1996). Dietary copper in excess of $200 \mathrm{ppm}$ amplifies proventicular enlargement and dilation (proventriculitis/proventriculosis) in broilers. Poultry Science Abstracts, p. 85. 